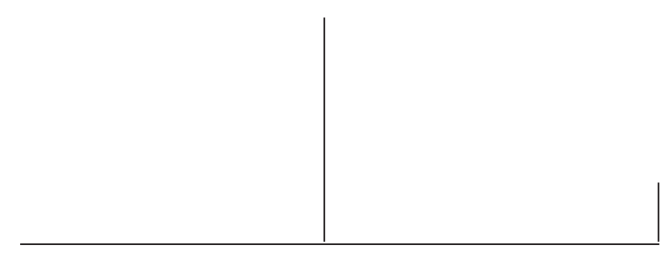

Rev. Latinoam. Psicopat. Fund., IV, 3, 47-60

\title{
O julgamento de Augusto Pinochet. Idéias sobre a relação memória-esquecimento na elaboração de traumas coletivos*
}

\author{
Alfredo Naffah Neto
}

\begin{abstract}
O presente ensaio, originalmente uma conferência, parte do acontecimento histórico da detenção do general Pinochet pela Inglaterra, em função de um processo movido por um juiz espanhol, para julgá-lo por crimes ocorridos no Chile, na época da ditadura militar. A partir daí, tematiza o papel do seu julgamento na elaboração do trauma coletivo chileno, discutindo a função da memória e do esquecimento na elaboração de traumas coletivos desse gênero. Utiliza uma perspectiva de análise simultaneamente psicanalítica e filosófica (nietzschiana).

Palavras-chave: Memória, esquecimento, trauma coletivo
\end{abstract}

* Este texto foi apresentado como conferência no II Congresso sobre Mal-estar e subjetividade, na Universidade de Fortaleza, Ceará, em março de 1999. 
A globalização tem das suas surpresas: num ato absolutamente inesperado, a Inglaterra resolveu deter o general Augusto Pinochet, a pedido do juiz espanhol Baltazar Garzón, atendendo a um processo jurídico pela tortura e assassinato de cidadãos espanhóis, na época da ditadura militar chilena. E o mundo assistiu ao evento estupefato. Por várias razões: a primeira delas é que os ditadores militares, até agora, sempre tinham encontrado formas de escapar impunes da justiça; Pinochet conseguira essa proeza em seu país, através de uma imunidade forjada a partir de um cargo de senador vitalício. A segunda é que a Inglaterra nunca foi, por tradição, muito preocupada com questões de justiça em terras estrangeiras; aliás, nos tempos de Margareth Thatcher, sempre foi uma aliada do ditador chileno. A terceira - talvez a mais contundente - é que, até então, só se assistira a atos de justiça executados desta maneira, em situações de guerra: somente então se esperaria que um país ousasse deter um cidadão de outro país, à revelia da justiça desse país. O próprio general nunca suspeitara que isso pudesse acontecer, caso contrário não teria escolhido um país estrangeiro do primeiro mundo para submeter-se a uma cirurgia de hérnia de disco. Surpresas do destino.

Logo surgiram as mais diferentes manifestações, a primeira delas de protesto do governo chileno, por se sentir desrespeitado em sua soberania: como a Inglaterra ousa deter um dos seus "senadores"? Com que direito o mundo ousa propor um julgamento que ele, Chile, não teve culhões para realizar no lugar e na época em que deveria ter ocorrido? É vergonha e humilhação o que transpira dessas reclamações, além - é claro - do medo de esse evento trazer novamente à tona o trauma coletivo da população chilena, forçado a um esquecimento prematuro. E isso efetivamente aconteceu: após a detenção do general, grupos de direita e de esquerda começaram a se degladiar em confronto aberto, pondo em risco a pretendida "paz" nacional chilena. Mas os protestos foram inúteis. Afinal, como bem disseram, o direito de a Inglaterra realizar esse ato não lhe veio somente dos efeitos da globalização na esfera da justiça, mas do fato de manter, com relação ao Chile, uma relação de superioridade, um olhar de cima, que lhe vem do fato de ser um país do primeiro mundo confrontando 


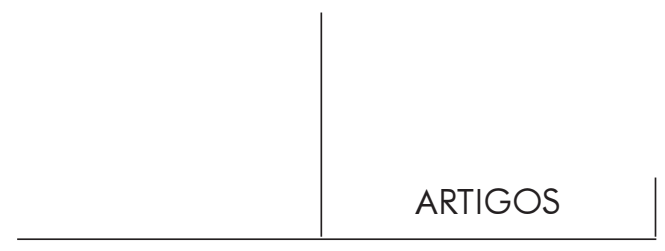

um do terceiro. O reverso seria muito menos provável, ou seja, o Chile ousar deter, por exemplo, Margareth Thatcher, a pedido de algum juiz argentino, por algum episódio envolvendo a guerra das Malvinas. A magnitude da ousadia geralmente tem a ver com o tamanho do cacife na mesa de jogo; o do Chile é reconhecidamente menor do que o da Inglaterra. Mas tudo tem limites: com a diplomacia de quem não quer se envolver em enrascadas, a Inglaterra acabou, por fim, acatando os resultados de uma junta médica - que dizia estar o general impossibilitado de julgamento por problemas de saúde - e libertando-o. O evento criou, entretanto, condições para que o Chile se sentisse criticado nos seus brios e iniciasse, ele próprio, um processo de julgamento do general, que teve como primeiro resultado a anulação de sua imunidade parlamentar no dia 8 de agosto de 2000.

Desde a detenção de Pinochet, pela Inglaterra, as manifestações do resto do mundo eclodiram por diferentes intensidades afetivas: ódio, medo e violência por parte da direita, ao ver a impunidade de um dos seus ídolos ser posta à prova; alegria e desejo de vingança por parte dos que sofreram na carne e no espírito, direta ou indiretamente, a selvageria do golpe de Estado chileno; consternação e cautela por parte dos juristas e chefes de Estado, que sempre preferem pôr as barbas de molho, por via das dúvidas. Poucos tiveram condições de uma avaliação lúcida e serena do acontecimento, como a que Isabel Allende - a sobrinha do presidente assassinado realizou num artigo publicado no jornal $O$ Estado de S. Paulo, no dia 24 de janeiro de 1999. Seu título: "Pinochet deixou no Chile um legado de medo". Gostaria de acompanhar e comentar as principais passagens do seu artigo, aproveitando a oportunidade para discutir o conflito entre memória e esquecimento e sua conformação na elaboração de traumas coletivos.

Isabel Allende começa historiando o acontecimento da detenção de Pinochet sob a alegoria da retenção mútua. Diz ela:

Quase uma década depois de entregar a presidência, o velho ditador conserva o governo democrático como refém. Mas, por enquanto, também o general está retido. Está em prisão domiciliar numa mansão de Londres, aguardando a decisão final sobre a extradição pedida por um juiz espanhol... (p. A16)

A metáfora exprime bem o poder simbólico, político, do general, capaz - naquele episódio - de mobilizar toda a instituição democrática chilena em sua defesa e a levar o presidente em exercício, inclusive, a pedir apoio dos países vizinhos, entre eles o Brasil. Tivemos que engolir uma declaração do nosso presidente, condenando publicamente a detenção de Pinochet, como ato arbitrário da Inglaterra, embora reconhecendo que o general merecesse o julgamento. Mas com que tipo de poder alguém consegue manter um governo democrático como refém? No presente caso, com o poder da barganha, da entrega do poder confiscado sob a condição de uma promessa de imunidade, num cargo de senador vitalício. Diz Isabel Allende: 


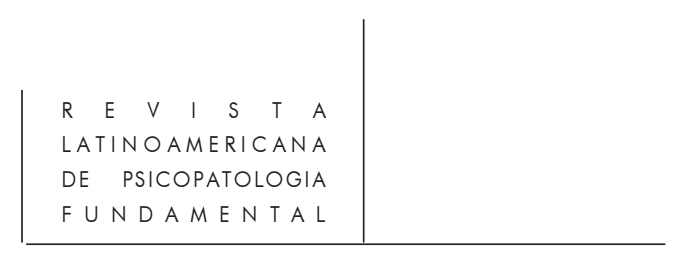

Antes de transferir o comando, Pinochet tratou de proteger-se e garantir que o poder continuasse em suas mãos. Continuou como comandante das Forças Armadas até 1988, ocasião em que se declarou senador vitalício. Nomeou senadores para garantir que a direita controlasse o Congresso, evitando emendas à Constituição que ele havia imposto ao país. Uma lei de anistia concedeu-lhe imunidade contra processos por quaisquer crimes cometidos durante seu regime. (Ibid.)

Ou seja, o general - sabendo dos crimes que cometeu - só aceitou entregar o poder sob a promessa de que o Estado o protegeria contra qualquer acusação. Não pensou que outro Estado mais forte pudesse desafiar esse poder do Estado Chileno, nem que - pelas repercussões internacionais geradas por esse desafio - essa imunidade pudesse lhe ser confiscada pelo próprio Estado Chileno, tal qual efetivamente aconteceu. Acasos da história.

Isabel Allende tinha, pois, plena razão, quando - muito antes disso acontecer - avaliara a detenção de Pinochet pela Inglaterra como promotora, em si mesma, da ruína moral do general. Diz ela:

Ao perseguir o general, instruir uma causa sólida e emitir o pedido de extradição, Garzón já conseguiu um resultado salutar: a ruína moral de Pinochet. Portanto, o homem que teve o desplante de fazer o papel de salvador de sua nação vai assumir seu lugar na companhia de Calígula e de Idi Amin. Mesmo que Pinochet nunca vá a julgamento, a justiça terá sido feita. (Ibid.)

Isabel define, pois, aí, o que entende como função maior deste ato jurídico: não necessariamente a prisão, dado que o general - a estas alturas - não representa mais uma fonte de perigo para a sociedade; não necessariamente, o castigo e a vingança aplicados conscientemente sobre aquele que produziu tanta ruína humana, pois essa postura define, apenas, a jurisprudência do ressentimento. No final do artigo, ela dirá:

Não sinto ódio de Pinochet. Ódio é um fardo muito pesado do qual me livrei muitos anos atrás, quando comecei a escrever. A literatura permitiu-me exorcizar a maioria dos meus fantasmas e transformar a minha dor em força (...) Não quero que o general apodreça na prisão como tantas de suas vítimas. Ele já sofreu uma inegável derrota que nada poderá transformar em vitória. (Ibid.)

Graças a essa transformação da dor em força - que Freud descreveria como sublimação - Isabel Allende nos oferece uma avaliação lúcida do ato jurídico em vez de uma interpretação ressentida, definindo a sua função maior como a de destruir um poder simbólico edificado num terreno moral. De "salvador da nação", Pinochet passaria - aos olhos do mundo - à condição de criminoso; essa seria a sua ruína moral. Inclusive porque ele não é o único responsável por tudo o que aconteceu. "Nem Hitler nem Pinochet poderiam ter existido - nos diz ela - sem o consentimento tácito ou explícito de milhões de cidadãos" (ibid.). Portanto, trata-se menos de julgar pessoas do que colocar em questão valores humanos. 


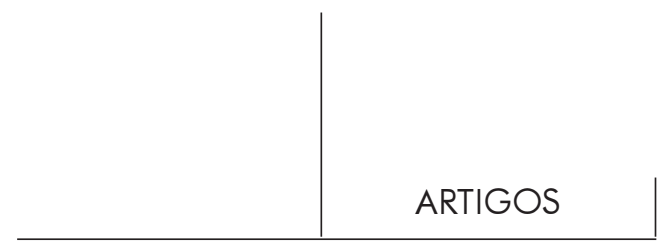

A questão maior que essas colocações nos suscitam tem a ver justamente com a noção de justiça ou, mais diretamente, com o sentido da justiça na esfera humana. Para que servem os atos jurídicos, capazes de condenar um criminoso a $\mathrm{x}$ anos de prisão, ou à morte (nos países onde vigora a pena máxima)? Embora a resposta mais evidente seja a que argumenta quanto à proteção da sociedade, ela é, hoje em dia, a menos capaz de se sustentar convincentemente. Sabe-se, através de pesquisas em países que possuem a pena de morte, que esse tipo de condenação não diminui a quantidade de crimes; talvez pela contradição de ela punir aplicando o mesmo ato pelo qual condena, trocando um assassinato por outro, simplesmente. A prisão, por outro lado, devido à precariedade das condições de vida propiciada aos prisioneiros - que atinge circunstâncias realmente sub-humanas em países como o Brasil - acaba por devolvê-los à sociedade muito pior do que entraram: mais ressentidos, violentos e com mais sede de vingança. Ou, pelo menos, com uma idéia de lei e de norma que não guarda mais qualquer relação com o código penal vigente. Todos sabemos que nossas prisões são verdadeiras escolas de marginalidade.

Recentemente, o médico Dráuzio Varella, no excelente livro que relata suas experiências no Carandiru de São Paulo (Varella, 1999), descreveu esse espaço marginal da prisão de forma humana e comovente. Não é que nele não impere alguma idéia de justiça ou de norma; afinal, os prisioneiros são seres humanos, como qualquer um de nós: não poderiam viver sem normas sociais de convivência entre eles. O que acontece é que os códigos criados para reger as normas da prisão não guardam mais qualquer correspondência com o código penal oficial. Exemplos disso são a condenação à morte dos estupradores, vigente no código interno à prisão e considerada crime pelo código oficial, ou a permissividade para o tráfico de drogas, vigente interinamente e também imputada como crime no mundo de fora.

$\mathrm{Na}$ esteira destas considerações, torna-se possível concluir que os atos de justiça não têm cumprido a função de proteger a sociedade: quando o fazem, é por tempo determinado e potencializando a marginalidade em alta escala. A que serve, pois, a justiça?

Serve à vítima, como forma de compensá-la, reparar os danos sofridos por ela, seria a segunda resposta possível: aqueles que fizeram sofrer, que produziram prejuízos materiais, afetivos ou morais, agora recebem na própria pele aquilo que praticaram. Esta segunda razão - que encontra sua máxima na lei de talião: "olho por olho, dente por dente" - aponta, pois, a vingança como a segunda justificativa para a justiça. Essa é, como já dissemos, a jurisprudência do ressentimento. Entretanto, os trágicos gregos já sabiam que ressentimento nomeia um afeto doentio, que envenena o espírito do seu portador. Na peça Édipo em Colono, de Sófocles, podemos encontrar Teseu advertindo Édipo, com relação ao seu rancor contra o filho Polinices. Diz o rei ao velho peregrino: "És tolo se não sabes que o ressentimento é 


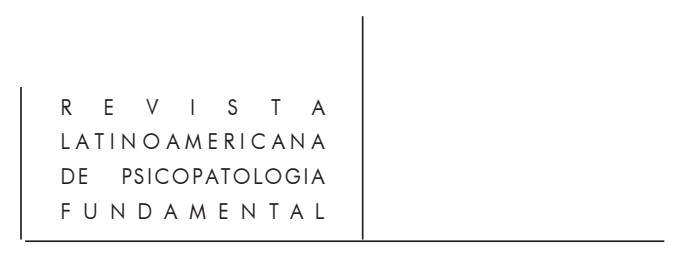

prejudicial durante a adversidade" (Sófocles, 1989: 136). Édipo provavelmente sabia disso mas, ainda assim, não conseguia livrar-se de tão incômodo sentimento, daí ser considerado um tolo pelo rei Teseu. Depois dos trágicos, Nietzsche dedicou vários textos e um livro inteiro - A genealogia da moral - à análise do caráter doentio do ressentimento, catalogando-o como a arma dos fracos, dos doentes de espírito. Segundo suas observações, o ressentimento mantém o seu portador escravizado ao acontecimento passado, reiterando ad-infinitum, e de forma passiva, o sentimento pelo qual foi invadido na ocasião geradora da dor ou da impotência traumatizantes; sem ação possível frente ao presente e ao futuro, o ressentido nutre-se de memória, vive de passado, sua vida só ganha sentido graças às fantasias de vingança geradas e temperadas na sua amargura. Seria, então, função da justiça funcionar como jurisprudência desse afeto doentio?

A questão é mais complicada do que pode parecer à primeira vista. Em primeiro lugar porque as vítimas, seus parentes e amigos, sempre reclamam e se sentem no direito de obter esse tipo de compensação moral, promotora de um lugar legitimado para a expressão do ódio coletivo gerado pelo crime. Todos se sentem autorizados a dar vazão a esse ódio, gozando com o sofrimento do criminoso - sua prisão ou execução -, visto tratar-se de um "ato de justiça", só se sentindo apaziguados após dita compensação. Um exemplo bastante claro dessa dinâmica pôde ser apreciado, há não muito tempo, por ocasião do assassinato da atriz Daniella Perez que, por se tornar rapidamente um acontecimento de mídia, promoveu identificações em massa com a dor, o ódio e a sede de justiça da mãe da vítima, a escritora de novelas Glória Perez, que declarara à imprensa que só encontraria paz com a condenação dos criminosos. Tinha ao seu lado legiões de telespectadores, de todos os tipos.

A função da vingança no apaziguamento da vítima (ou seu representante) constitui tema bastante explorado pelas diferentes formas de arte, desde que a humanidade existe e produz algum tipo de cultura, tendo sido especialmente tematizada pela literatura, o teatro, a ópera. $\mathrm{O}$ assassinato de Clitemnestra por seu filho Orestes, como vingança pelo assassinato de seu pai Agamêmnon na tragédia Oréstia, de Ésquilo, do século V a.C.; e o assassinato de Leonora por seu irmão Don Carlo, como vingança pelo fato de seu amante Don Alvaro ter acidentalmente morto seu pai, na ópera la Forza del Destino, de Verdi e Maria Piave, segunda metade do séc. XIX da era cristã, ilustram apenas dois pontos distantes de uma longa cadeia. É possível concluir, pois, que a vingança como forma de justiça está nas origens da nossa cultura, portanto, da nossa constituição subjetiva. Difícil, senão impossível, extirpála da nossa idéia e vivência emocional de justiça; como bem diz o termo, ela define uma compensação moral e a humanidade ainda se define fundamentalmente por seu estofo moral. Entretanto, nós psicanalistas sabemos que a vingança tem uma função meramente catártica: se o ato de conseguir deter o criminoso e castigá-lo, ainda que 


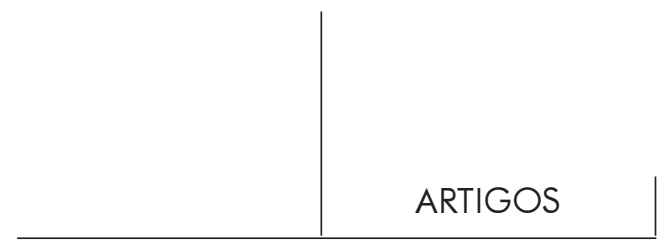

tardiamente, consegue apaziguar o sentimento de culpa de algum parente ou amigo da vítima - que imagina que poderia tê-la protegido do crime e se culpa por não têlo conseguido - esse efeito é superficial e passageiro. A vingança não tem qualquer papel positivo na elaboração da dor e do luto; pelo contrário, tende a substitui-la e deslocá-la indefinidamente, buscando lenitivos para a dor fora dela. Conforme já disse num artigo anterior, a transformação da dor em ódio posterga qualquer processo de elaboração psíquica, pois

... enquanto a dor, para ser vivida e digerida, requer necessariamente um locus subjetivo, uma solidão produtiva, o ódio pode ser projetado e introjetado incessantemente no circuito intersubjetivo. Isso produz um jogo interminável que, ao mesmo tempo, cria a ilusão de um sujeito potente e perpetua a interpretação odiosa/odienta pelo deslocamento constante do afeto de um lado para o outro. Odiar/ser odiado torna-se, então, o afeto reiterado como ressentimento. (Naffah Neto, 1998: 60-61)

Para que haja elaboração psíquica, é preciso que o ódio ceda novamente lugar à dor e que esta possa ser sustentada e vivida em toda a sua contextura. Viver a dor significa, num primeiro momento, desistir de explicá-la - pela criação de responsabilidades e culpas - ou de apaziguá-la - pela produção de compensações e reparações morais - para poder enfrentá-la em toda a sua crueza inominável, inexplicável, incompensável. Enfrentá-la, sustentá-la e, então, poder transformá-la, pela elaboração do luto. Isabel Allende nos conta que conseguiu isso sublimando a dor e transformando-a em literatura; por isso pode pensar esse ato de justiça menos como julgamento da pessoa do general Pinochet do que como avaliação dos valores que ele encarnou e realizou.

Entretanto é preciso salientar que, se todas essas ponderações colocam em xeque as formas conhecidas de justiça que as legislações vigentes têm colocado ao nosso dispor, isso não significa que se esteja defendendo aqui uma sociedade sem leis. É óbvio que toda sociedade tem o direito de se defender do crime e de proteger os seus cidadãos; a questão intrincada é saber como fazê-lo de forma efetiva, visto que as formas vigentes até aqui não têm conseguido realizar tal tarefa a contento. Mais complicada se torna ainda a questão quando o próprio Estado encarna o criminoso.

É para explicitar essa dimensão da questão, que o artigo de Isabel Allende envereda pela história do Chile: da época de Salvador Allende, passando pelo golpe de Estado, até os dias de hoje. Começa relembrando-nos que Allende foi eleito por uma minoria de $36 \%$ e por uma coalizão de vários partidos, a Unidade Popular (UP), extremamente dividida e em luta. Luís Claudio Figueiredo, brasileiro, psicanalista, professor universitário e meu amigo, tendo vivido no Chile de Allende, como exilado político durante o ano e meio final antes do golpe, contou-me, num depoimento pessoal, que o presidente tinha, apesar disso, um grande apoio popular. Apesar de ter sido eleito por uma minoria, essa era a população mais politizada do Chile, a que, de 


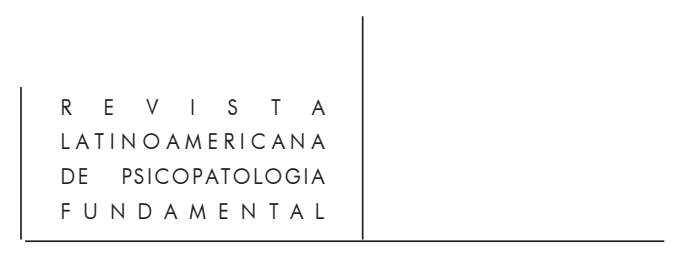

fato, arregaçava as mangas da camisa para realizar algo. O resto da população compunha uma grande parcela de Democracia Cristã - que, como todas as suas congêneres, mantinha-se em cima do muro - e uma direita extremamente conservadora, mas de pequeno tamanho. Luís Claudio conta que as manifestações de apoio ao presidente conseguiam reunir nas ruas de Santiago cerca de um milhão de pessoas, em dias de verdadeira festa coletiva: cantava-se, dançava-se, comia-se, discursava-se e as famílias saíam em bloco, dos avôs aos netos. Sendo o Chile, por tradição, um país extremamente zeloso das instituições democráticas - e nesse ponto o artigo de Isabel Allende e o depoimento de Luís Claudio convergem - era quase impossível suspeitar de um golpe de Estado, mesmo quando o país começou a receber uma série de boicotes tanto externos quanto internos, a inflação disparou e a escassez teve início. Luís Claudio pondera corretamente que, sem o apoio da Democracia Cristã, a direita chilena, de pequeno porte, nunca teria conseguido essa proeza; Isabel Allende aponta, além disso, a ajuda fundamental da CIA americana. De qualquer forma, foi somente já muito perto do golpe, ou seja, perto do plebiscito que Allende pretendia, e não pôde convocar, que um certo clima desagradável começou a alastrarse; foi mais ou menos nessa época que começaram a se formar filas para se obter vistos de saída do país, principalmente por parte dos exilados políticos. A imprevisibilidade do golpe serviu para tornar impossível qualquer defesa contra ele; a necessidade de dizimar toda a população organizada, que apoiava o presidente, tornou inevitável a intensidade e crueza da sua violência.

Imaginem um país atravessado por uma alegria de reconstrução social, com uma parcela politizada, ativa e organizada da população trabalhando com o governo democraticamente eleito para propiciar a todos o fundamental para a vida cotidiana; e que conseguia, inclusive, atravessar épocas da escassez pois, como lembra Luís Claudio, devido aos produtos de pesca - sempre abundantes - nunca chegava, de fato, a faltar alimento. Os boicotes da direita atingiam tal porte que, de tempos em tempos, descobriam-se grandes depósitos clandestinos de alimento estocado, comprado e guardado, para que a população permanecesse na penúria. Isso além de a burguesia abastada financiar greves de caminhoneiros, comerciantes, médicos, durante meses e meses, com a finalidade de enlouquecer a classe média e dispô-la a apoiar uma intervenção das Forças Armadas ${ }^{1}$. Nada disso, entretanto, conseguia destruir a confiança coletiva, a alegria de viver, o clima de festa descontraído, cantado por poetas e músicos, celebrizado na Peña dos Parras. Imaginem a erupção, no interior desse clima, do bombardeio do Palácio de la Moneda, quando o presidente, querido e respeitado, viu-se encurralado, sem saída, discursando no rádio para os seus

1. Um retrato fiel desses boicotes foi realizado pelo filme "Chove sobre Santiago", dirigido por Helvio Soto, e disponível atualmente sob forma de videocassete. 




cidadãos até o último momento de vida. Pensem no tamanho da impotência de todos. E no terror que se seguiu nos dias seguintes, em que helicópteros metralhavam qualquer edifício onde houvesse suspeita de livres atiradores, obrigando os moradores a passarem dias inteiros amontoados entre os elevadores e o saguão central dos prédios, como conta Luís Claudio. E nas noites de intensos bombardeios, em que as ruas amanheciam cheias de cadáveres. E no toque de recolher que, de início, vigorava durante todo o tempo, sendo posteriormente levantado no período entre dez e dezoito horas; quem saísse à rua nos horários proibidos era automaticamente fuzilado; quem ficasse em casa, obedecendo à ordem, poderia receber a visita da polícia, nas revistas coletivas. Estas eram realizadas, de quando em quando, em busca da população envolvida com o governo, que era numerosa; qualquer suspeito era levado para o Estádio Nacional e de lá para a tortura e, muitas vezes, à morte. Diz Isabel Allende: "Centenas de presos foram jogados de aviões no mar - depois de ter os ventres abertos para que afundassem - ou explodidos, ou enterrados por motoniveladoras" (ibid.). Era preciso dizimar todo aquele trabalho coletivo pela violência nua e crua, criar uma memória do terror, marcada a ferro e fogo, para que qualquer outra tentativa de desafiar os poderosos nunca mais acontecesse. A Democracia Cristã, que apoiara o golpe, logo teve que se afastar da direita, ao perceber que perdera o controle sobre o nível de barbárie dos atos do governo; voltava, assim, à sua posição habitual, em cima do muro. E o general Pinochet, até então um ilustre desconhecido, tornouse do dia para a noite o homem mais poderoso do Chile, posição que, só muito recentemente, começou a perder.

Freud nos diz, em "Para além do princípio do prazer", que o que cria o efeito traumático de um acontecimento não é tão-somente a intensidade da sua violência, mas também, e principalmente, o seu caráter imprevisível, que impede a formação de uma angústia capaz de preparar os sujeitos para o que vai acontecer. No Chile de Salvador Allende o golpe de Estado teve esse caráter: explodiu como terreno minado, totalmente imprevisível, mas abrindo fossos e deixando cicatrizes, na memória popular, impossíveis de serem destruídas: marcas eternas, sempre em guarda, velando aquelas lembranças como um parente vela um morto. Como todo trauma, este - ainda que coletivo - pôde se resolver provisoriamente pelo processo inconsciente do recalcamento, reforçado por mecanismos sociais de disfarce, na linha do slogan: "tudo já passou e somos novamente uma grande família”. O drama parecia, então, praticamente esquecido; entretanto, bastou que algum acontecimento viesse esbarrar nas suas cicatrizes para que, de repente, tudo retornasse: a detenção de Pinochet teve esse caráter. Então percebeu-se o óbvio: que nada havia sido elaborado ainda, apenas forçado a um esquecimento prematuro.

Memória-esquecimento, dois momentos de um só processo, que poderíamos evocar pela metáfora nietzschiana de uma marca gravada a ferro e fogo sobre a pele 


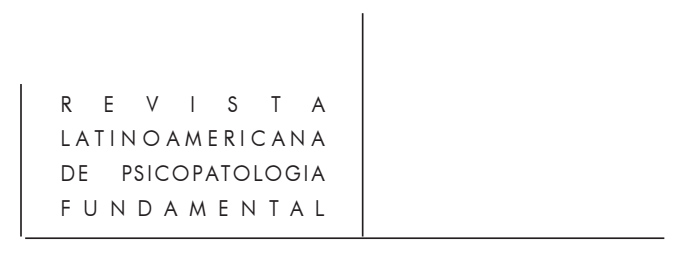

e que, com o tempo, torna-se apenas cicatriz, mais ou menos perceptível, mais ou menos sensível. Se a dor da ferida tiver sido insuportável, ela muito dificilmente poderá ter sido cuidada adequadamente, supurada; terá sido apenas anestesiada e tido uma cicatrização superficial. E para que passe desapercebida, a cicatriz terá perdido a função de referi-la e velá-la, bem como de evocar o acontecimento que a produziu, tornando-se uma marca sem sentido, recobrindo a pele como uma pinta ou uma verruga. Vive-se ainda a ferida - que continua viva como antes -, mas como algo disperso, deslocado, metamorfoseado, rarefeito, uma espécie de angústia sem lugar. Entretanto, um esbarrão mais violento na cicatriz, ou simplesmente um estímulo presente que evoque o acontecimento passado que a produziu, e todas as lembranças e dores estarão de volta. A esse apagamento inconsciente da memória, associado a uma cicatrização superficial, Freud nos ensinou a chamar de recalcamento. Há também aquele tipo de cicatrização profunda, vigente quando se pôde suportar a dor da ferida por um tempo maior: então, todo o tecido lesado terá recebido a devida atenção e cuidado, tendo sido avaliadas e curadas as afecções/infecções, transformados os afetos e criado espaço psíquico pré-consciente para a memória traumática. Nesse caso, a cicatriz pode descansar serena na nossa pele e até mesmo ser acariciada, sem que tudo retorne como se fosse presente. Ela continua capaz de evocar o acontecimento, mobilizar lembranças que podem, certamente, produzir alguma dor, mas estas podem encontrar um lugar no corpo, no espírito e, principalmente, no tempo: passado e presente permanecem distintos. Esse processo Freud chamou de elaboração psíquica; graças a ele, a lembrança traumática - que estaria relegada a um espaço inconsciente - pode ganhar espaço psíquico pré-consciente, não sendo mais necessária a sua invasão presente, em busca de espaço, alocação. Isso possibilita o que Nietzsche chamou de esquecimento.

No caso do Chile, dizia justamente que não houve, nem pôde haver esquecimento real, devido à força da violência produzida e à cicatrização superficial e forçada, deixando a ferida enquistada e escondida. É óbvio que alguns pontos desse tecido social e político - representados por subjetividades singulares, como Isabel Allende -, puderam encontrar resolução própria, mas é provável que a extensão da ferida escondida seja incomensuravelmente maior do que seus pontos escassos de cicatrização mais profunda. A detenção de Pinochet trouxe novamente tudo à tona: as dores, os ódios, os sentimentos de culpa.

Os autores da violência e os que a apoiaram dizem hoje, para mitigar sua culpa e responsabilidade, que Pinochet salvou o país do comunismo e que essa missão the foi confiada por Deus (cf. Isabel Allende, ibid.). Conversa para tolos e pobres de espírito, senão para canalhas. O comunismo caiu por si mesmo das árvores onde vicejou, fruta podre que não chegou a amadurecer, nem a ser saboreada; não necessitava de nenhum embuste heróico para atirá-la ao chão. E quanto a Deus, já 




morreu há muito tempo, sem deixar representantes autorizados. Quanto ao governo chileno, seu argumento inicial apoiava-se num evitamento da convulsão social a que poderia levar um julgamento de Pinochet; pretendia, pois, conseguir disfarçar a ferida e, com o tempo, novamente encobri-la. Hoje, já se propõe a um julgamento do ditador no seu próprio país: o mundo inteiro aguarda para ver o que vai acontecer, de fato.

Por ocasião da detenção do general pela Inglaterra, discutiu-se muito o quanto ela teria sido legítima, tanto quanto o seu julgamento na Espanha. Como outras detenções do mesmo tipo podem vir a acontecer no mundo contemporâneo, vale a pena nos determos um pouco nessa questão. Não pretendo entrar nos aspectos jurídicos da mesma, visto não ser esta a minha especialidade; vou tentar respondêla de um ponto de vista ético. Começarei discutindo os argumentos que defendem a ilegitimidade da sua detenção.

O primeiro deles pondera que a Espanha não teria o direito de julgar Pinochet, que os seus crimes só poderiam ser julgados no Chile. Este argumento tem seus pontos frágeis em dois aspectos: o primeiro deles é que houve, efetivamente, cidadãos espanhóis que foram vítimas de tortura e genocídio e que esses crimes não foram julgados ainda; o segundo é a desconfiança geral de que, no Chile, o julgamento venha a acabar em pizza, devido a todo o apoio com que Pinochet ainda conta em seu país (principalmente, o das Forças Armadas). Nada impediria, pois, de um ponto de vista ético, que a Espanha viesse a realizar tal julgamento, tivessem os acontecimentos históricos tomado outro rumo.

Ao segundo argumento, que diz que não convém remexer em feridas antigas, sob o risco de produzir convulsões sociais de desfecho imprevisível, tentei responder durante todo esse percurso. Não é deixando traumas não elaborados caírem num esquecimento prematuro - seja pelo recalque inconsciente ou pelo disfarce social que se pode obter a paz numa nação. Um esquecimento efetivo só pode ser obtido por meio da elaboração psíquica que, infelizmente, só pode se processar no âmbito singular de cada grupo, cada família, cada subjetividade, e que tem o seu tempo próprio, diferente em cada caso. Mas há um outro processo - de outra índole e ocorrendo num outro âmbito - que pode ser complementar a esses processos de cicatrização psíquica; trata-se de uma avaliação das forças que movimentaram as ações criminosas, geradoras dos traumas, e das conjunturas que a desencadearam. Indo ainda mais além, tratar-se-ia de uma avaliação dos valores humanos envolvidos na sua produção. No caso que estamos examinando, esse processo poderia ser desencadeado pelo julgamento de Pinochet.

É evidente que o julgamento de um criminoso desse porte movimenta ódios e desejos de vingança incomensuráveis (principalmente por parte das vítimas, visto que a direita já deu a entender que, quando considerar o referido julgamento como causa perdida, deixará de empunhá-lo como bandeira). Esse seria, entretanto, o efeito menos 
importante, meramente catártico. Mais fundamental que isso seria poder avaliar que forças, em que condições, podem produzir instintos sanguinários num grupo de homens, e os levar, durante um golpe de Estado, a jogar pessoas de aviões, após ter aberto seus ventres ou a explodi-las ou a enterrá-las com motoniveladoras. Ou a quebrar as mãos de um cancioneiro maravilhoso como Victor Jara e obrigá-lo a tocar violão de mãos quebradas. Valores de que ordem podem promover e justificar tamanha barbárie?

Entretanto, como diz Isabel Allende, "nem Hitler nem Pinochet poderiam ter existido sem o consentimento tácito ou explícito de milhões de cidadãos". Portanto, não se trata de julgar a pessoa do general, mas as forças que o movimentaram e, ao mesmo tempo, cooptaram o apoio de milhões de cidadãos. Essas forças, esses valores é que deveriam ser o verdadeiro objeto de julgamento. Entretanto, as sociedades humanas só sabem julgar pessoas; todo ato jurídico é fundamentalmente moral, vingativo e punitivo. Que seja assim, então. Mas que esse julgamento possa - mesmo que seja por um efeito secundário - colocar-nos um pouco mais em contato com essas forças assassinas, sádicas, paranóides, que não habitam tão-somente as entranhas do general, mas, em maior ou menor grau, a de qualquer ser humano.

Isabel Allende arremata o seu texto dizendo que gostaria que o general fosse julgado “... para que a verdade sobre seus crimes fosse plenamente revelada." $\mathrm{E}$ conclui, dizendo: "Só então, com o reconhecimento dos erros passados, poderá começar a verdadeira reconciliação dos chilenos" (ibid.; grifos meus). Eu diria que a sua conclusão ainda é tributária de uma certa metafísica, visto que o que está em questão não são verdades ou erros e sim valores; trata-se mais de debater uma ética, do que de perseguir "a verdade" dos fatos; inclusive porque sempre existirão várias versões de um mesmo fato. Trata-se - isso sim - de dar voz às versões abortadas, reprimidas, àquelas que nunca puderam vir a público e, por vezes, sequer serem formuladas; realizar um inventário das diferentes versões dos fatos e das forças que as constituem e movimentam.

Tampouco é o caso de se imputar ao general uma "censura moral" que, segundo Isabel Allende, seria pior que a prisão. Ou de o general pedir perdão às suas vítimas. É curioso que um artigo que se desenvolve tão bem em quase toda a sua trajetória, tropece nas suas conclusões e tangencie um final hollywoodiano. Será que a ferida não foi totalmente purgada? Será que algum resquício de ressentimento ainda se esconde nas dobras dessa alma, ansiando por algum tipo de vingança? Ou serão apenas reverberações da nossa cultura cristã?

De qualquer forma, no conjunto do artigo, concordo com Isabel Allende. Às vezes, percebo, no fundo de mim mesmo, um personagem que gozaria com o julgamento de Pinochet e que se alegraria intensamente ao vê-lo apodrecer na prisão. Não reprimo esses afetos, mas sei que se trata apenas do meu lado ressentido, 


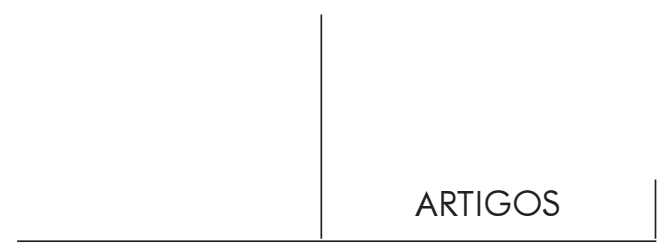

vingativo, pegando carona na causa chilena. No fundo, sei que pouco importa o destino de Pinochet: se será considerado culpado ou se continuará impune, para muitos um exemplo de um herói nacional ${ }^{2}$. O rumo dessa trajetória pessoal acrescentará muito pouco, quase nada, ao destino da humanidade como um todo: apenas um efeito catártico de alívio ou o incremento do ressentimento, para aqueles diretamente implicados nos seus atos criminosos ou identificados às causas em questão. Mas sei, como psicanalista, que essa catarse tem pouco - ou nenhum - valor curativo e que os ressentimentos demandam outro tipo de elaboração. Tampouco espero que ele peça perdão às vítimas: não o julgo capaz disso. Quanto às censuras morais, penso que elas só servem para perpetuar a razão maniqueísta, a oposição entre Bem e Mal, lembrando que foi por uma avaliação dessa índole que os golpistas justificaram seus crimes (identificando os "comunistas" como o Mal, a ser dizimado a qualquer preço). Mas o julgamento de Pinochet valerá a pena se puder ajudar a pesquisar, um pouco mais, o lado escuro, assassino, demoníaco, que nos habita, que habita todo homem, constituindo o seu avesso do avesso do avesso.

\section{Referências bibliográficas e musicográficas}

Allende, I. Pinochet deixou no país um legado de medo. O Estado de S. Paulo. São Paulo, 24 de janeiro de 1999.

Ésquilo. Oréstia. Rio de Janeiro: Jorge Zahar, 1991.

Freud, S. Más allá del principio de placer. Obras Completas. Buenos Aires: Amorrortu, 1986. v. XVIII.

Naffah Neto, A. Para além da morte, o amor... In Outr'em-mim - Ensaios, crônicas, conferências. São Paulo: Plexus, 1998.

2. Quando este texto sofreu sua última revisão, no dia 30 de janeiro de 2001 , a sequiência dos acontecimentos envolvendo um possível julgamento de Pinochet era a seguinte: após a cassação de sua imunidade parlamentar, em agosto de 2000, ele foi informado por um tribunal chileno de que deveria submeter-se a exames mentais e neurológicos para avaliar suas condições de poder vir a a ser julgado. Em seguida, o juiz Gusmán ordenou a sua prisão domiciliar, com base nas denúncias de homicídio e seqüestro qualificado, mas o Supremo Tribunal Chileno suspendeu a ordem de prisão, atendendo a apelação dos advogados de defesa, reordenando exames mentais e interrogatórios prévios. Os exames foram, finalmente, realizados (de 10 a 12 de janeiro de 2001), acusando uma "demência de branda a moderada", resultante de acidentes vasculares. No dia 23 de janeiro, o juiz Gusmán interrogou Pinochet, que se declarou inocente, no dia 26 ele foi internado devido a uma ameaça de derrame cerebral. Mas, horas antes da internação, um ex-subordinado seu deu declarações à imprensa, desmentindo a declarada inocência de Pinochet e acusando-o de ter ordenado execuções ilegais. Assim, no dia 29, o juiz Gusmán ordenou novamente a sua prisão domiciliar. 




NiETZsChe, F. Genealogia da moral. São Paulo: Brasiliense, 1988.

Sófocles. A trilogia tebana. Rio de Janeiro: Jorge Zahar, 1989.

Varella, D. Estação Carandiru. São Paulo: Companhia das Letras, 1999.

Verdi, G. M. \& Maria Piave, F. La força del destino. Ópera em quatro atos. EMI Records LTd., 1955.

\section{Resumos}

Este ensayo, originalmente una conferencia, parte de la ocurrencia histórica de la detención del general Pinochet por Inglaterra, por motivo de una causa criminal impetrada por un juez español, a fin de juzgarlo por transgresiónes cometidas en Chile, en el período de la dictadura militar. En seguida, analiza el rol de su juzgamineto en la elaboración del trauma colectivo chileno y debate la función de la memoria y del olvido el la elaboración de traumas colectivos de este género. Una análisis simultaneamente psicoanalítica y filosófica (Nietzsche) es su herramienta de trabajo.

Palavras llave: Memoria, olvido, trauma colectivo

Cet essai, originellement une conférence, part d'un événement historique: la détention de général Pinochet par l'Angleterre, due à un procès promu par un juge espagnol, pour le juger des crimes exécutés dans Chili pendant la phase de la dictature militaire. A partir de ce fait, l'éssai analyse la fonction de ce jugement dans le processus d'élaboration du traumatisme collectif chilien et discute la fonction de la mémoire et de l'oubli dans l'élaboration de traumatismes collectifs de ce genre. Il utilise une perspective d'analyse simultanément psycanalytique et philosophique (Nietzsche).

Mots clés: Memoire, oubli, traumatisme collectif

This essay, originally a conference, has its start point in a historical event: Pinochet's arrest by England, because of a juridical process moved against him by a Spanish judge, concerning crimes occurred in Chile during the military dictatorship. Then the text analyses the role his judgement plays in the process of working over Chile's collective trauma, discussing the function of memory-oblivion in working over that kind of collective traumas. It follows a theoretical perspective which moves between psychoanalysis and philosophy (F. Nietzsche).

Key words: Memory, oblivion, collective trauma

Versão inicial recebida em fevereiro de 2001

Versão revisada recebida em agosto de 2001 